\title{
Effectiveness of mindfulness on resiliency and cognitive distortion of patients with physical symptoms
}

\author{
Parisa Pourabadei ${ }^{1}$, Farzad Yousefinia $^{2}$ \\ 1-PhD Student in Psychology, Department of Psychology, Lorestan University, Khorramabad, Iran. \\ 2- Master of Clinical Psychology, Department of Psychology, Fars University of Medical Sciences, Shiraz, Iran \\ (Corresponding Author). $\quad$ E-mail: farzad_psychologist@yahoo.com
}

Received: 22/03/2020 Accepted: 09/06/2020

\begin{abstract}
Introduction: The presence of physical and psychological complications in psychosomatic disorders leads to defective cognition and distorted beliefs about the disease, which can interfere with effective coping with the disease and its acceptance as part of life.

Aim: The aim of the present study was to investigate the effectiveness of mindfulness on the resilience and cognitive distortion of patients with physical symptoms.

Method: in the present quasi-experimental study, among the people with somatic symptoms referred by a specialist to the psychological clinics of Isfahan in 2019, 30 patients with psychosomatic disorder who were referred to the Kelid Talaei Zehn clinic were selected by convenient sampling based on diagnosis of psychiatrist and physician and according to the inclusion criteria and were placed in control and experimental groups by random sampling. Participants were assessed three times (pretest, posttest, one-month follow-up) by the Questionnaires of Resiliency and Cognitive Distortion. Data were analyzed by ANOVA with repeated measure test.
\end{abstract}

Results: The results showed that mindfulness was effective on increasing resiliency $(\mathrm{p}<0.01)$ and reducing cognitive distortion $(\mathrm{p}<0.01)$ and its components in patients with somatic symptoms. Mindfulness reduces cognitive distortions through cognitive flexibility and cognitive defusion

Conclusion: Mindfulness leads to cognitive changes and reduces cognitive dissonances and increases resiliency by change coping strategies from avoiding to acceptance of emotions and thoughts, creates self-awareness and avoid automatic thinking pattern and can be used as training in rehabilitation and improving the quality of life in patients with psychosomatic disorders.

Keywords: Mindfulness, Resiliency, Cognitive dissonance, Somatic symptoms

How to cite this article : Pourabadei P, Yousefinia F. Effectiveness of mindfulness on resiliency and cognitive distortion of patients with physical symptoms. Shenakht Journal of Psychology and Psychiatry. 2020; 7 (3): 16-31 .URL: http://shenakht.muk.ac.ir/article-1-712-en.pdf

Copyright ( $\odot 2018$ the Author (s). Published by Kurdistan University of Medical Sciences. This is an open access article distributed under the terms of the Creative Commons Attribution-Non Commercial License 4.0 (CCBY-NC), where it is permissible to download, share, remix, transform, and buildup the work provided it is properly cited. The work cannot be used commercially without permission from the journal. 


\title{
بررسى اثربخشى ذهن آكاهى بر تاب آورى و تحريف شناختى بيماران با علائم جسمانى
}

\author{
يريسا يور آبادئى '، فرزاد يوسفى نيا'

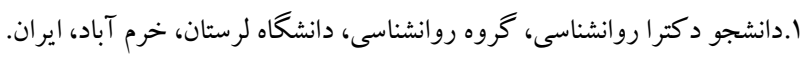

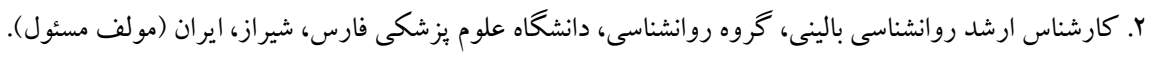

ايميل: farzad_psychologist@yahoo.com

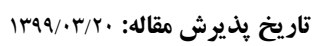

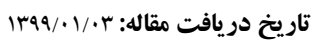

جكيده

مقدمه: عوارض جسمى و روانشناختى در اختلالهاى روانتنى موجب شناخت معيوب و باورهاى تحريف شده درباره بيمارى مىشود

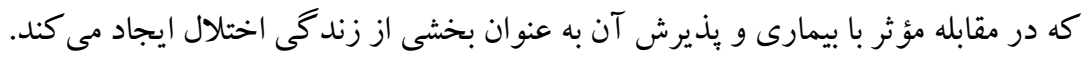
هدف: هدف يُزوهش حاضر بررسى اثربخشى ذهن آكًاهى بر تاب آورى و تحريف شناختى بيماران با علائم جسمانى بود. روش: در يزوهش شبه آزمايشى حاضر، از افراد با علائم جسمانى ارجاع شده توسط يزشك به كلينيكهاى روانشناختى شهر اصفهان

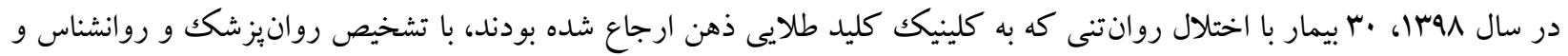

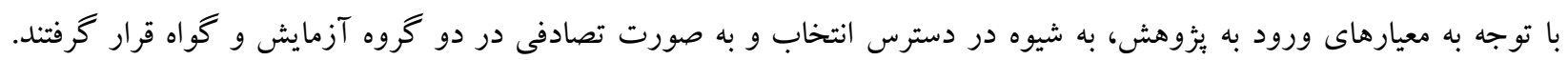

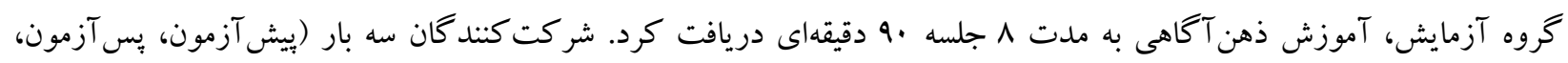

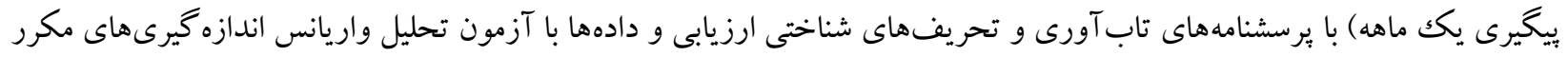
تجزيه و تحليل شدند.

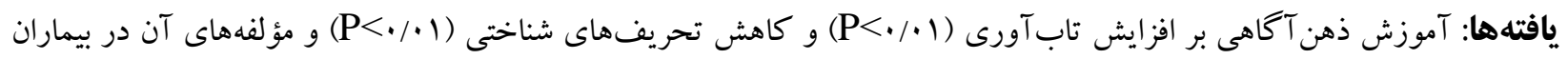

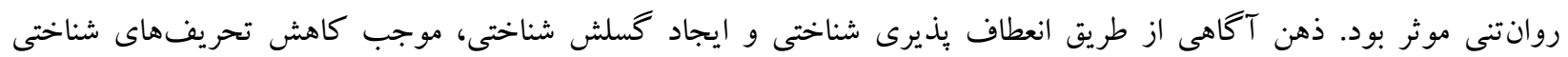
مى گردد.

نتيجه كيرى: ذهن آكاهى با تغيير راهبردهاى مقابلهاى از اجتناب به يذيرش احساسات و افكار، ايجاد خودآكاهى و اجتناب از تفكر

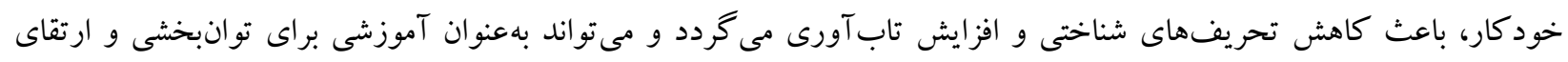
كيفيت زندگى بيماران مبتلا به اختلالات روانتنى به كار روده. كليدوازهها: ذهن آكاهى، تابَآورى، تحريف هاى شناختى، علائم جسمانى 
افزايش خطر رنج و ناراحتى، مرگك يا ناتوانى بر بيمارى

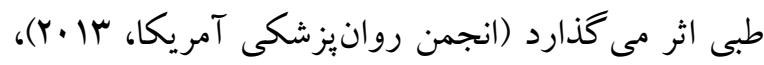
تحريفهاى شناختى " يكى از عوامل روانشناختى است روتى

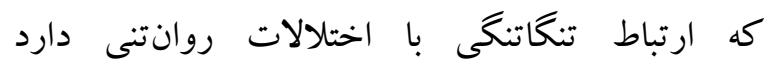

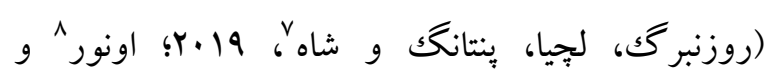

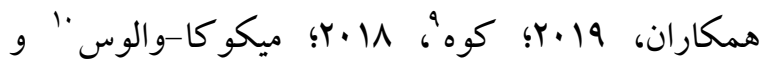

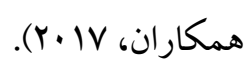
تحريفات شناختى الخوهاى تفكرى هستند كه ارزيابى فرد از موقعيتها و فشارهاى روانى را تحت تأثير قرار مىدهد و با تغيير ديدكاه آنها نسبت به خود، دنيا، آينده، اعتقادات و و نخرشهايى كه دارد، سبب افزايش آسيبيذيرى در برابر اختلالات هيجانى مىشود (بلير،

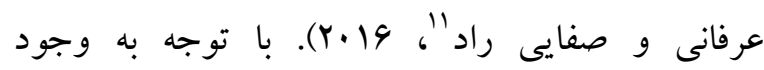
شكايتهاى جسمى متعدد آزار دهنده در افراد مبتلا به اختلالات روانتنى، تحريفات شناختى مى توانند علاوه بر كاهش نگرش مثبت به خود يا فقدان آن، درك قضاوت كرانهاى نسبت به نقايص خود در افراد ايجاد كنند كه در يكك جرخهى معكوس موجب تشديد علائم آنها گردد

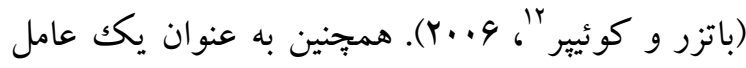
آسيب:ذيرى فرد ناشى از شرايط تنشزاى محيطى تلقى مىشوند كه مىتواند علائم روانتنى را افزايش دهند به اين صورت كه نوع نخرش اشخاص نسبت به خود، دنيا

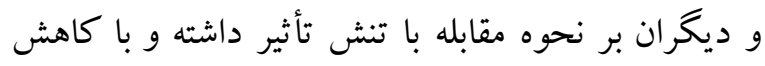
احساس كنترل بر تنث ناشى از رويدادهاى مهم زندگىى،

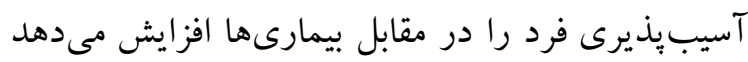
به طورى كه ممكن است موجب شكل گيرى اختلال

${ }^{6}$ - Cognitive distortion

7- Rosenberg, Lechea, Pentang \& Shah

${ }^{8}$ - Onur

${ }^{9}$ - Koh

${ }^{10}$ - Mikocka-Walus

11- Belir, Erfani \& Safaeerad

${ }^{12}$ - Butzer \& Kuiper
بررسى سير بيمارىها در قرن اخير نشان مىدهد كه نوع معهد

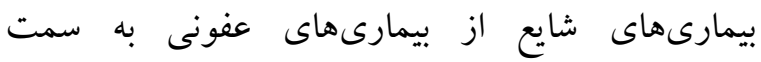

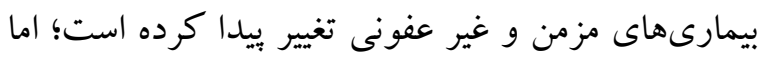
مسئله مهم در دهههاى اخير، ظهور نوع جديدترى از بيمارىها با عنوان اختلالهاى روانتنى است (كوتزمن،

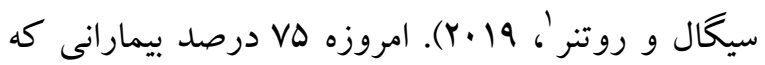
به يزشكان عمومى و داخلى مراجعه مى كنند، دجار واكنشهاى روانتنى بوده و از عوارض آن رنج مىبرند

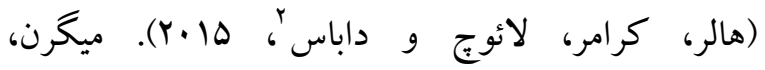
سردردهاى تنشى، تهوع و استفراغ، كوليت مزمن (ورم مزمن روده بزركَ)، آسم، جوش و آكنه، واكنشهاى آلرزى، كهير، كاهش قند خون، افزايش ترشح غدد داخلى، ديابت نوع دو، جاقى، فشار خون اساسى، بيمارى كروز قلب و افزايش ضربان قلب كه در آنها حوادث يرمعناى روانشناختى به طور تنگاتنگى با نشانهاى بلدنى

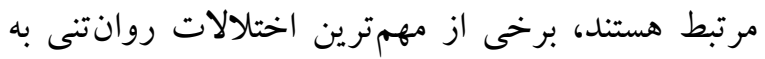

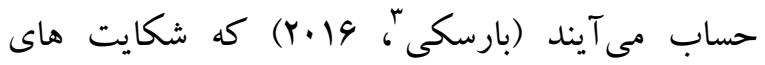

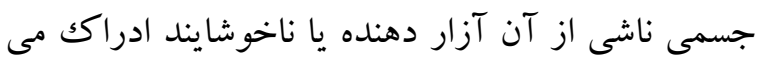

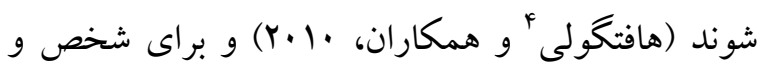
جامعه بار اقتصادى زيادى به همراه دارند، عملكرد شغلى، تحصيلى، بين فردى و ... را تحت تأثير قرار مىدهند و از

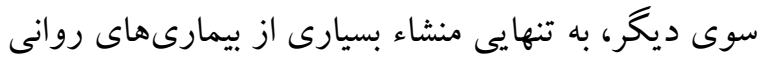

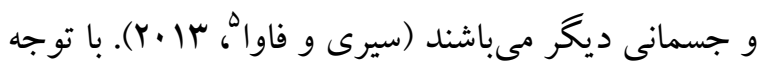
به اين كه ويزگ كى اصلى عوامل روانشناختى مؤثر بر بيمارىهاى طبى، وجود يكك يا جند عامل مهم بالينى روانشناختى يا رفتارى است كه به شكلى زيانآور با لـان

\footnotetext{
1- Goetzmann, Siegel \& Ruettner

2 - Haller, Cramer, Lauche \& Dobos

3 - Barsky

${ }^{4}$ - Haftgoli

5 - Sirri \& Fava
} 
موقعيتهايى، به عنوان سير در برابر ويامدهاى ناشى از

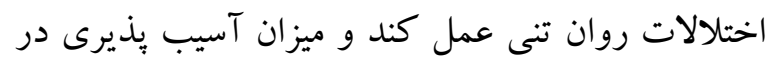
مقابل آن رابه طور قابل توجهى كاهش دهد (يانگك، ليو،

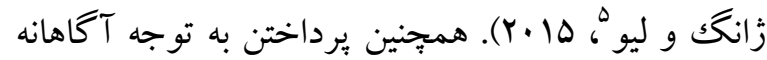
و توسعه ارتباط يذيرش بيشتر با تجربه لحظه حال، مىتواند به افراد در رها كردن عادتها و عدم ارائه واكنشهاى غير مفيد براى تجربههاى تنشزاى فعلى، موجب انتخاب واكنشهاى بهترى گردد كه از ميزان

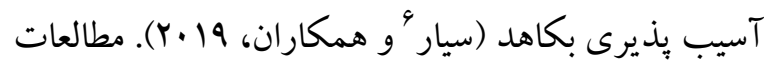
مطالعات مختلفى اثربخشى ذهن آكاهى در كاهش

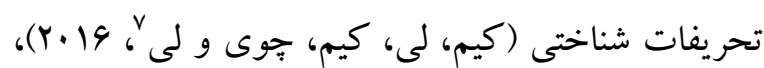
بيمارىهاى مزمن (بولميجر، :برنگر، تال و كوئيبرز،

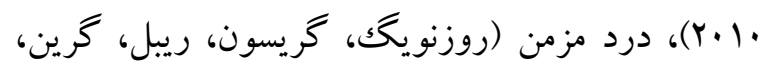

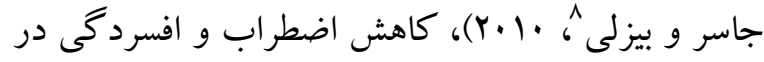
بيماران مبتلا به ام.اس (كلاه كج و زر گر، ها +r)، كاهش

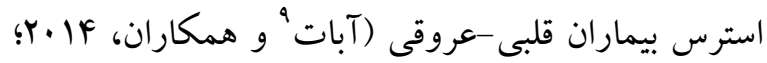

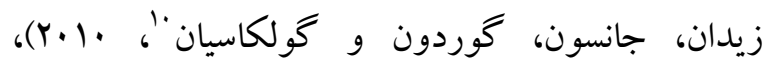

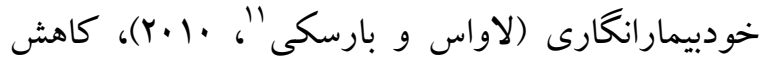
اختلالات اضطرابى (وولستاد، سيورستن و نيئلسون،

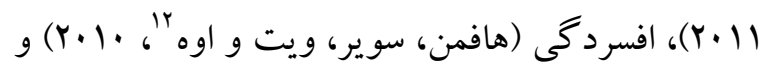

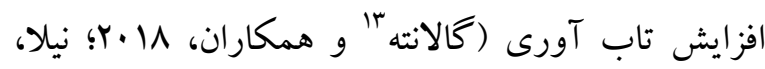

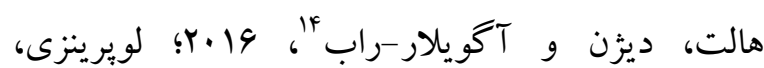
يراساد، اسكرودر و سوودها، (1) دادهاند.

5- Yang, Liu, Zhang \& Liu

6- Sayyar

7- Kim, Lee, Kim, Choi \& Lee

8- Rosenzweig, Greeson, Reibel, Green, Jasser \& Beasley

9 - Abbott

${ }^{10}$ - Zeidan, Johnson, Gordon \& Goolkasian

${ }^{11}$ - Lovas \& Barsky

${ }^{12}$ - Hofmann, Sawyer, Witt \& Oh

${ }^{13}$ - Galante

${ }^{14}$ - Nila, Holt, Ditzen \& Aguilar-Raab

15 - Loprinzi, Prasad, Schroeder \& Sood
روانتنى خاصى همجيون سردردهاى تنشى شود (ياشل' و و همكاران، Y +. Y)؛ بنابر اين ظرفيت مقابله آنها با شرايط دشوار و ارائه بِاسخ انعطافيذير به فشارهاى مختلف

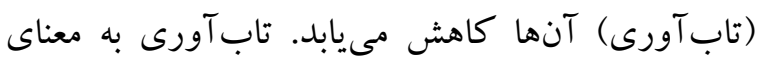
توانايى مقابله با شرايط دشوار و وياسخ انعطافيذير به فشارهاى زندكى روزانه است. روانشناسان هميشه سعى كردهاند كه اين قابليت انسان را براى ساز كارى و غلبه بر رور خطر و سختىها افزايش دهند. افراد و جوامع مىتوانند حتى بِ از مصيبت هاى وير انگر به بازسازى زندكى خود بيردازند. فردى كه داراى تاب آورى است جارهساز و و انعطافيذير است. مطابق تغييرات محيطى خود را وفق مىدهد و يس از برطرف شدن عوامل فشارزا بهسرعت به

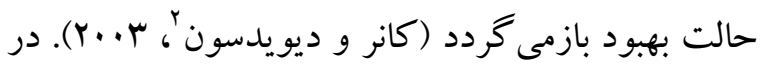
اين راستا، مداخلات و آموزشهايى كه در كاهش تحريفهاى شناختى و افزايش تابآورى و به طور كلى بهبود وضعيت سلامت افراد و ايجاد شرايط مطلوب در زمان كوتاه براى تبديل حالتهاى هيجانى و افكار منفى وصى به حالتهاى هيجانى و افكار مثبت، بسيار مفيد خواهد بود. به همين دليل، يكى از مداخلاتى كه مىتواند مورد

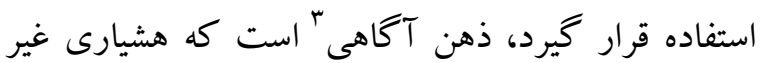
قضاوتى، غيرقابل توصيف و مبتنى بر زمان حال نسبت به تجربهاى است كه در يكك لحظه خاص در محدوده توجه فرد قرار دارد و اعتراف به تجربه يادشده و يذيرش آن را

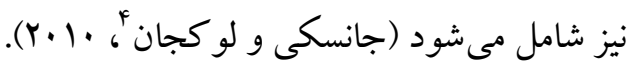
ذهن آكاهى ممكن است با تغييرات در ديدكاه فرد نسبت به خودش و افزايش توانمندى در سازش با انواع موقعيتهاى تنشزا و بر جالش و مديريت مؤثر جنين

\footnotetext{
1- Yücel

2- Connor \& Davidson

3 - Mindfulness

4- Janowski \& Łucjan
} 
كرده بود كه هيج توضيح بزشكى قانع كنندهاى بر مبناى آزمايش ها و معاينات بيمار براى شكايت بيمار از سردردهاى شديد، تنگى نفس يا مشكلات گوارشى وجود ندارد ؛ لذا بيمار از لحاظ مشكلات روحى روانى سي بررسى كردد. روانيزشك و روانشناس كلينيك بِ از از مصاحبه بالينى با بيمار و بررسى علائم بيمار بر اساس معيارهاى اختلال علائم جسمانى مطابق با بنجمين

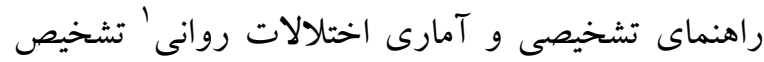
اختلال علائم جسمانى را در برونده بيمار ثبت كردند. كروه نمونه به صورت در دسترس از بين مراجعه كنند كان داراى اختلال روان تنى كه توسط روانيزشك و بز بزك بـك به كلينيك كليد طلايى ذهن ارجاع داده شده بودند، انتخاب شد و يس از مصاحبه بالينى و اطمينان از وجود اختلالات روانتنى، ·ץ نفر به صورت تصادفى در دو

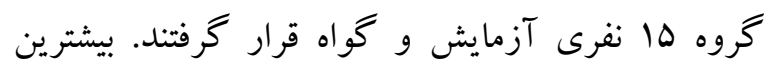
علائم بدنى بيماران شكايت از تنكى تنفس و حملات شبه

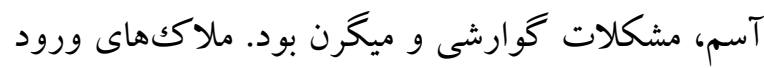
به بززوهش شامل آكاهى از شركت در جلسات، سن بين

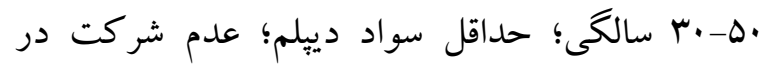
جلسات رواندرمانى طى 9 ماه كذشته و عدم ابتلا به سايكوز بودند. ملاكك خروج نيز عدم شركت در يكك جلسه از روان درمانى بود. در جلسه اول، هدف يثوهش و آزمايش براى شركتكنندها تشريح و به سؤالهاى احتمالى آنها توسط

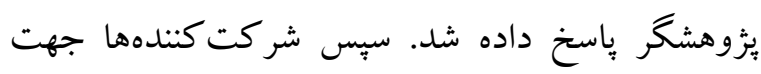

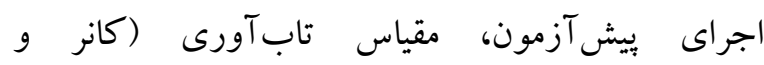

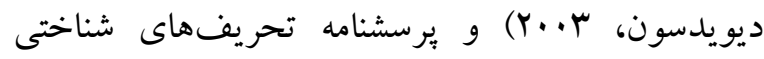

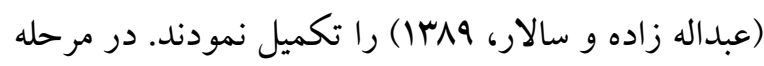

\footnotetext{
1. Diagnostic and Statistical Manual of Mental Disorders (DSM-5)
}

اختلالات روانتنى بر جنبهاى مهم كار كرد فرد به طور

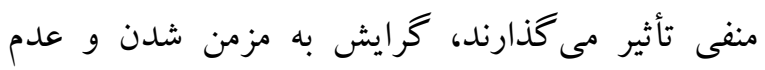

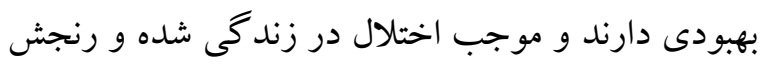
روانى فراوانى را به همراه دارند. ممكن است تمام عمر ادامه يابد و بهطور كلى اختلالى ناتو ان كننده محسوب مى لى شوند كه در درازمدت اثرات نامطلوبى در سبك زند آنى فرد و اطرافيان وى بر جاى مى كذارد. با توجه به حضور نخرشهاى منفى در افراد مبتلا كه تأثيرات قابلتوجهى بر بر برد نوع سبكهاى مقابلهاى آنان دارد و همجنين توجه متمر كز آنان بر علائم و نشانههاى خود، وجود مداخلهاى كه بتو اند در كوتاه مدت، به كاهش تحريفات شناختى و از سوى ديخر، افزايش تابآورى آنها ببردازد، بيش از

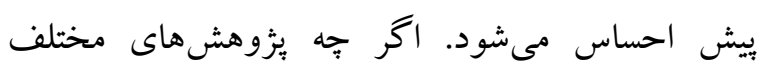
اثربخشى ذهن آكاهى را در رابطه با بيمارىهاى مزمن مورد تائيد قرار دادهاند؛ اما نكتهاى كه در مطالعات بوريشين مورد بررسى قرار نگرفته است، تأثير آموزش ذهن آكاهى بر تحريفات شناختى و تاب آورى در بيماران مبتلا به اختلالات روانتنى بوده است و اين سؤال به وجود آمد كه ذهن آكَاهى با توجه به ماهيتش مى تواند در راستاى كمكك به بيمار ان مبتلا به اختلالات روانتئ به به به كار كرفته شود يا خير؛ بنابر اين بثزوهش حاضر به بررسى اثربخشى ذهن آكاهى بر تابآورى و تحريف شناختى بيماران با علائم جسمانى برداخت.

در يثزوهش شبه آزمايشى حاضر، جامعه آمارى شامل كليه مراجعه كنند كان داراى علائم جسمانى بود كه از طريق بزشك به كلينيكهاى روانشناختى شهر اصفهان در سال ^هَ| ارجاع داده شده بودند. متخصصى كه بيمار رابه مركز روانتنى ارجاع داده بود در معرفى نامه ذكر 
رعايت شده است يكى از اين ملاحظات اخلاقى در نظر

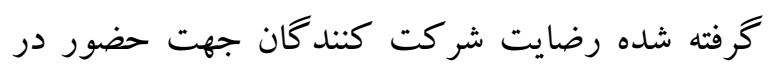
يزوهش مورد نظر بود و همجنين در صورت عدم تمايل،

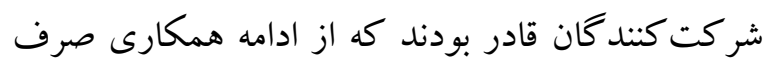
نظر كنند. دادن اطمينان به شركت كنند كان كه اطلاعات آنها محرمانه خواهد بود و بدون اجازه از آنها اين اطلاعات انتشار نخواهد شد يكى ديخر از اين ملاحظات الهماته

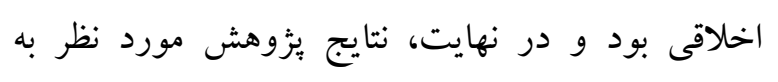

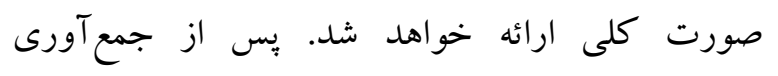
اطلاعات، دادهها توسط نرمافزار سץ SPSS و با استفاده از آزمون آمارى براى تحليل واريانس با اندازه مكرر مورد تجزيه و تحليل قرار خرفتند.

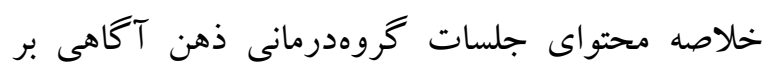
اساس يروتكل كابات زين در جدول شماره 1 ارائه كرديده است.
بعد، جلسات مداخله ذهن آكاهى بر اساس محتوى

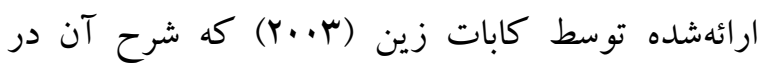
جدول شماره ا آمده است، براى مداخلات مبتنى بر ذهن

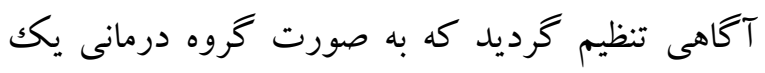
جلسه در هفته به مدت •qه دقيقه توسط روانشناس آموزش ديده در زمينه ذهن آكاهى و داراى سه سال سابقه كار در كلينيك روانشناسى كليد طلايى ذهن شهر اصفهان بر گزار شد. گروه كنترل بهعنوان ليست انتظار در نظر

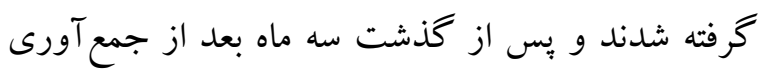
نتايج بيخيرى براى گروه كنترل نيز جلسات روان درماند

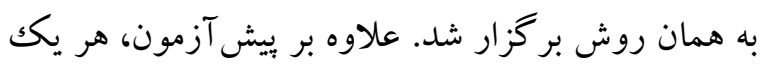
از بيماران دو بار ديخر (بايان درمان و بيخيرى يككماهد) بلهوسيله مقياس تابآورى (كانر و ديويدسون، ب...ب) و يرسشنامه تحريفهاى شناختى (عبداله زاده و سالار،

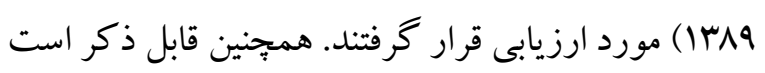
كه در اين بزُوهش ملاحظات اخلاقى توسط يزوهشخران

جدول ا ساختار و محتواى جلسات ذهن آكاهى

\begin{tabular}{|c|c|}
\hline 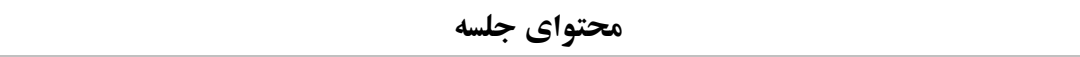 & جلسه \\
\hline خو شامد كويى، معرفى اعضا و بيان ساختار جلسات، قوانين و مقر رات مربوطه & اول \\
\hline معرفى مفهوم ذهن آكاهى و آثار مخرب اجتناب تجربهاى & دوم \\
\hline آموزش تمرينهاى غير رسمى و رسمى توجه آكاهى & سوم \\
\hline 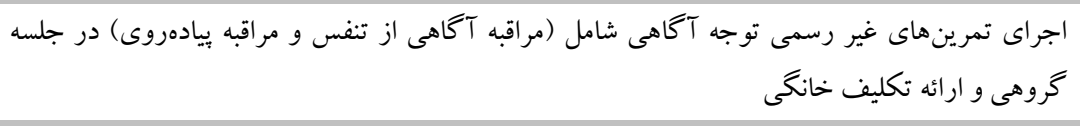 & 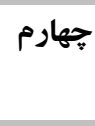 \\
\hline بركنى تكاليف خانكى جلسه قبل و ارائه بازخورد. آموزش تمرينهاى رسمى ذهن آكاهى شامل (تمرين & 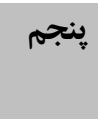 \\
\hline 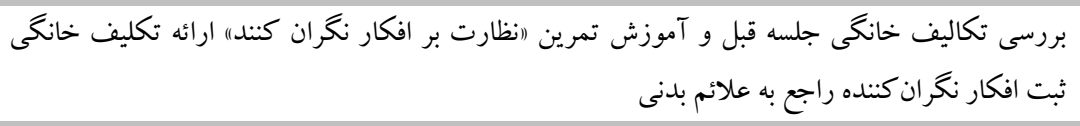 & ششم \\
\hline 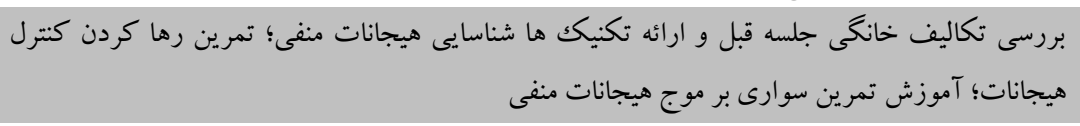 & هفتم \\
\hline آهوزش نحوه استفاده از تمرينهاى ذهن آكاهى در زند گى روزمره و ارائه تكاليف خانكى مربوطه & 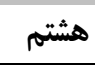 \\
\hline
\end{tabular}


شخصى سازى) توسط البرت اليس مى بردازد. اين

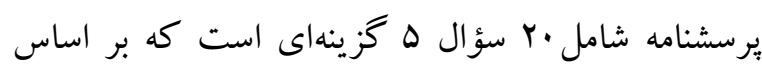
مقياس ليكرت (1-ه) نمره كذارى مىشود. اين برسشنامه داراى اعتبار و روايى داخلى است. اين آزمون توسط عبداله زاده و سالار در سال 14091 بر روى جمعيت ايرانى، |ه| زن و أl| مرد هنجاريابى شد. براى تعيين همسانى درونى برسشنامه تحريفهاى شناختى از آزمون آلفاى كرونباخ استفاده شد كه ضريب آلفا به دست آمده به صورت استاندارد برابر با (•^/•)، است (فرمانى، بهمنى و قائدنياى جهرمى، 94Mا). به همين سبب مى توان نتيجه كرفت كه آزمون حاضر از همسانى درونى مناسبى برخوردار است. در يثزوهش حاضر نيز مقدار آلفاى

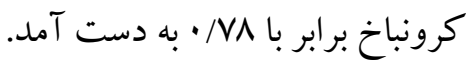

\section{يافتهها}

كروه آزمايش، شامل ^ زن و V مرد بودند در حالى كه

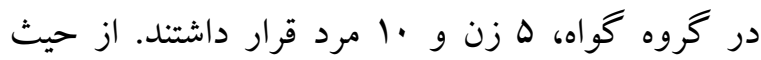

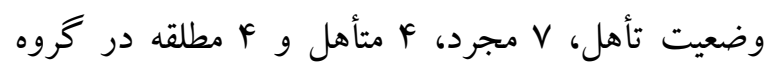
آزمايش و V مجرد، Y متأهل و 9 مطلقه در گروه گواه حضور داشتند. در كروه آزمايش، 4 نفر ديبلم، ب نفر كاردانى، ه نفر كارشناسى و ا نفر مدرك ارشد و بالاتر

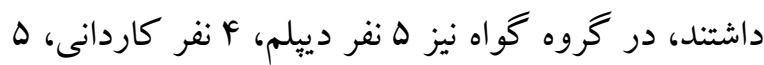
نفر كارشناسى و ا نفر داراى مدرك ارشد و بالاتر بودند. ميانگين و انحر اف معيار سن در گروه آزمايش، به ترتيب

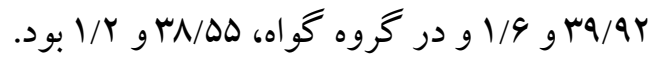
ميانگين و انحراف استاندارد متغيرهاى تابآورى و و ورون تحريفهاى شناختى در سه مرحله قبل از مداخله (ييش -

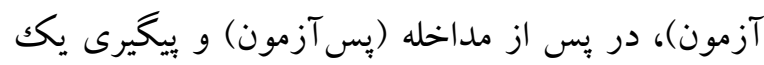

ابزارهايى كه در اين يُوهش مورد استفاده قرار كرفتند،

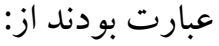
مقياس تابآورى كانر- ديويدسون (CD-RISC) ؛ اين مقياس توسط كانر و ديويدسون (r.....) براى سنجش تابآورى تهيهشده و ابزار هائ سؤالى است كه سازه تاب آورى را در اندازههاى ينجدرجهاى ليكرت از صفر تا جهار مىسنجد. حداقل نمره تابآورى آزمودنى در اين مقياس صفر و حداكثر نمره وى صد است. نتايج مطالعه مقدماتى مربوط به ويز گیىهاى روانسنجى اين مقياس، يايايى و روايى آن را تائيد كرده است. همسانى درونى،

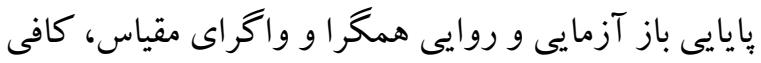
كزارش شدهاند. در بيزوهش حق رنجبر، كاكاوند،

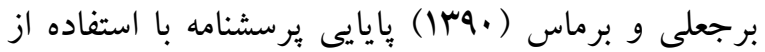
آزمون ضريب آلفاى كرونباخ مورد آزمون قرار گرفت كه آلفاى AF/ • براى اين يرسشنامه به دست آمد. بايايى

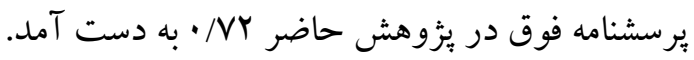
يرسشنامه تحريفهاى شناختى: برسشنامه حاضر توسط عبداله زاده و سالار (1) (I) با هدف دست يابى به ابزارى آسان براى آكاهى از تحريفهاى شناختى استفاده شده

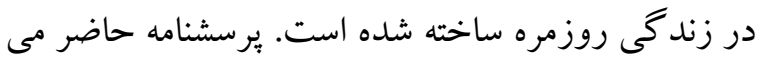
تواند به عنوان يكك ابزار، در خدمت اهداف آموزشى، يثزوهشى، بهداشتى درمانى، در رابطه با كار و روابط انسانى، مديريت و سازماندهى و سياست گذارى مورد استفاده قرار كيرد. اين :برسشنامه بر مبناى تحريفهاى شناختى اليس ساخته شده است و به سنجش ·. اتحريف شناخته شده (همه يا هيج، تعميم مبالغه آميز، فيلتر ذهنى،

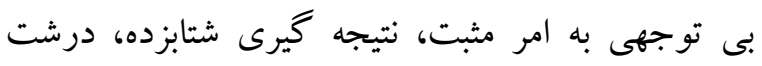
بينى - ريز بينى، استدلال حسى، بايد- بهتر، برجسب زدن،

\footnotetext{
1. Connor- Davidon, Resilience scale (CD- RISC)
} 


\section{جدول r ميانكين و انحراف استاندارد تابآورى و تحريفهاى شناختى و مؤلفهاى آن به تفكيك تروه}

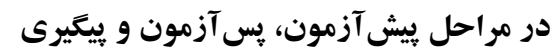

\begin{tabular}{|c|c|c|c|c|c|c|c|}
\hline \multicolumn{2}{|c|}{ ييَيرى } & \multicolumn{2}{|c|}{ بعد از مداخله } & \multicolumn{2}{|c|}{ قبل از مداخله } & \multirow[b]{2}{*}{ كروهها } & \multirow[b]{2}{*}{ متغير } \\
\hline استحر اف اندارد & ميانكين & استحراف افنارد & ميانكين & انتافراف أنارد & ميانكين & & \\
\hline$\Lambda V / A r$ & $1 \cdot / \mathrm{VI}$ & IT/YT & $\Lambda r / r$ & $r \mu / \cdot \Lambda$ & $W / 94$ & آازمايش & تابآورى \\
\hline $1 \Delta / V \Lambda$ & $9 \Delta / V \pi$ & $10 / T^{4}$ & $9 V / I r$ & $18 / 99$ & $90 / 19$ & كواه & \\
\hline$\Delta / \wedge \varphi$ & $r V / F D$ & $\Delta / V V$ & $r \Delta / r r$ & $\Delta / I V$ & $F I / A F$ & 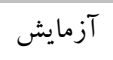 & تحريفهاى \\
\hline$F / \Lambda$ & $F \cdot / \Delta q$ & $F / \Delta \Delta$ & $f \mid / f$ & $\Delta / / F$ & FI/rT & كو اه & شناختى \\
\hline$\cdot$ • & $r / \Lambda$ & $\cdot 19 \mathrm{~V}$ & $r / \Delta$. & $\cdot / 99$ & $r / r \Delta$ & آزمايش & درشت بينى \\
\hline$\cdot / 90$ & $r / 9 \Delta$ & $1 / 19$ & $r / 19$ & $1 / Y F$ & $r / \cdot \Lambda$ & كواه & \\
\hline $1 / r \Delta$ & 每 & $1 / H F$ & $r$ & $1 / \mu V$ & $r / \cdot 1$ & آزمايش & استدلال احساسى \\
\hline $1 / \pi r$ & $r / 9 \Delta$ & $1 / F F$ & $r / \cdot 1$ & $1 / \Delta r$ & $F / 19$ & كواه & \\
\hline $1 / 1 r$ & $\Delta / F$ & $\cdot / 19$ & $\Delta / V \Delta$ & $1 / \cdot 1$ & $9 / 1$ & آزمايش & برجسب زنى \\
\hline $1 / F F$ & $\Delta / \Delta$ & $1 / \Delta 9$ & $\Delta / 9$ & $1 / 94$ & $\Delta / V$ & كواه & \\
\hline$\cdot / 90$ & $r / V$ & $\cdot / \mathrm{M}$ & $r / \mu r$ & $\cdot / 99$ & $r / 91$ & آزمايش & بايد - بهتر \\
\hline $1 / r$ & $r / r r$ & $1 / \cdot 1$ & $r / \cdot \Lambda$ & $1 / 1 Y$ & $r$ & كواه & \\
\hline$\cdot / V 9$ & $r / N r$ & .190 & r r/r & $1 / 19$ & $r / \cdot \Lambda$ & آزمايش & شخصى سازى \\
\hline$\cdot / A F$ & $r / \cdot r$ & $\cdot / 99$ & $r / r \Delta$ & $\cdot / \wedge r$ & $r / 19$ & كواه & \\
\hline $1 / \Delta \Delta$ & $r / \mu$ & $1 / r V$ & $F / \Delta$ & $1 / r$. & $f / 9$ & آزمايش & همه - هيج \\
\hline $1 / 9$ & $r / 9$ & $1 / 9 Y$ & $F / 91$ & $r / Y \Lambda$ & $F / \wedge r$ & كواه & \\
\hline $1 / H F$ & $F / V$ & $1 / \cdot 1$ & $F / \Delta$. & $1 / 10$ & $F / 94$ & آزمايش & تعميم دهى \\
\hline $1 / 9$ & $F / F$ & $1 / 9 Y$ & $F / r$ & $r / \cdot r$ & $F / F 1$ & كو اه & \\
\hline $1 / 94$ & $F / r q$ & $1 / 49$ & r/Ar & $\mid / / 1$ & $\Delta / \cdot \Lambda$ & آزمايش & فيلتر ذهنى \\
\hline$\cdot / 19$ & $F / A V$ & $\cdot / N$ & $\Delta$ &.$/ 94$ & $\Delta / 19$ & كواه & \\
\hline $1 / 9$ & $r / 1$ & $1 / F Y$ & r/va & I/V9 & $F / V D$ & آزمايش & بى توجهى \\
\hline$I / Y F$ & $f / 94$ & $1 / 49$ & $F / r$ & $1 / 89$ & $F / \mu r$ & كواه & \\
\hline $1 / \cdot r$ & $r / \cdot r$ & . & r/Ar & $\cdot / 91$ & r & 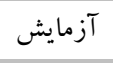 & نتيجه كيرى \\
\hline $1 / r$ & $r / F r$ & $1 / \Delta \Delta$ & $r / 94$ & $1 / 0$ & $r / \Delta$. & كواه & شتابزده \\
\hline
\end{tabular}

نتايج جدول Y در متغيرهاى وابسته در مرحله يس آزمونو

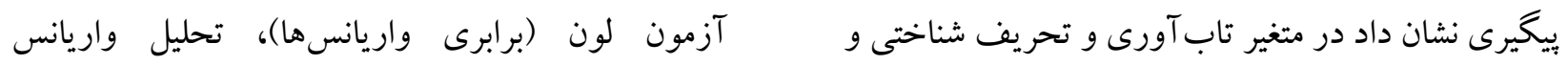

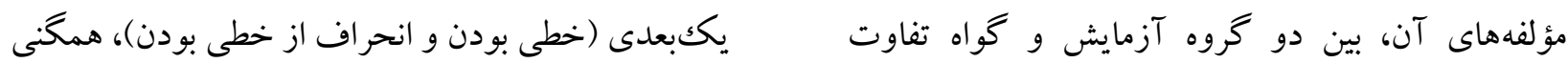

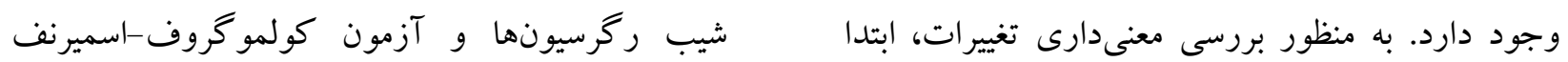

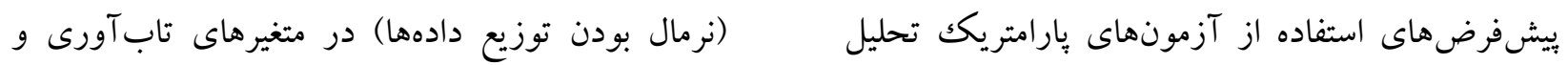


تحريفهاى شناختى و مؤلفههاى آن نشان داد كه خطى بودن و نرمال بودن توزيع دادهها براى انجام تحليل

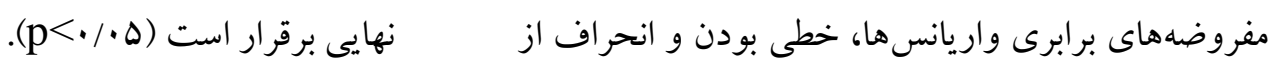

\begin{tabular}{|c|c|c|c|c|c|c|}
\hline معنادارى & $\mathbf{F}$ & مجذورات مينَين & آزادى درجه & مجذمورات & مراحل & متغير \\
\hline$\cdot / \cdot 1^{* * *}$ & N/q1 & $\Delta G / Y q$ & 1 & $\Delta G r / Y q$ & مِس آزمون & \\
\hline$\cdot / \cdot l^{* * *}$ & $\Delta 9 / N \wedge$ & $r F \Delta / r \Lambda$ & 1 & YFO/YA & ييخيرى & تابآورى \\
\hline$\cdot / \cdot 1^{* * *}$ & $r I / r$ & $\mid r / r \Lambda$ & 1 & $\mid r / \pi \Lambda$ & بِ آزمون & تحريفهاى \\
\hline$\cdot / \cdot 1 r^{*}$ & $19 / \cdot r$ & $\mid r / \Delta F$ & 1 & $\mid Y / \Delta F$ & 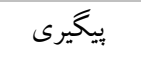 & شناختى \\
\hline.$/ \cdot 19^{*}$ & $V / a q$ & $r / T V$ & 1 & $r / T V$ & سֶ آزمون & درشت بينى \\
\hline$\cdot \cdot r 1^{*}$ & $V / F F$ & $r / 11$ & 1 & $r / 11$ & بي بيخيرى & \\
\hline.$/ 19^{*}$ & $V / A q$ & $\Delta / M_{q}$ & 1 & $\Delta / r q$ & 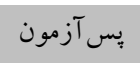 & استدلال احساسى \\
\hline$\cdot / \cdot r \Lambda^{*}$ & $V / M F$ & F/AD & 1 & $F / A \Delta$ & ييخيرى & \\
\hline$\cdot / r r$ & $r / \Delta \Delta$ & $1 / \pi T$ & 1 & $1 / \pi$ & بِ آزمون & برجسب زنى \\
\hline$\cdot / 19$ & $r / A V$ & $1 / 4 \Delta$ & 1 & $1 / \% \Delta$ & ييخيرى & \\
\hline$\cdot / \cdot q^{* * * *}$ & $Q / \Delta F$ & T/AT & 1 & $r / F T$ & 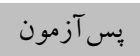 & بايد - بهتر \\
\hline.$/ \cdot 19^{*}$ & $\Lambda / F$ & $r / l F$ & 1 & $r / l F$ & بيخيخىى & \\
\hline$\cdot / \cdot f^{* * *}$ & $\mid r / A$. & $r / \Delta \Lambda$ & 1 & $r / \Delta \Lambda$ & يس آزمون & شخصىسازى \\
\hline$\cdot / \cdot 1 f^{*}$ & $1 . / 9 \mathrm{~V}$ & $r / \cdot V$ & 1 & $r / \cdot V$ & بيخيرى & \\
\hline$\cdot|r|$ & $r / T r$ & $\cdot / 90$ & 1 &.$/ 90$ & بِ آزمون & همله - هيج \\
\hline$\cdot / \pi \Delta$ & $r / 91$ & $1 / 1$ & 1 & $1 / 1$ & ييخيرى & \\
\hline$\cdot / 14$ & $1 / 9$ & $\cdot / N$ & 1 & $\cdot M r$ & 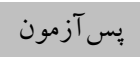 & تعميم دهى \\
\hline$\cdot|r|$ & $1 / 9$ & .19 & 1 & .19 & ييخيرى & \\
\hline$\cdot / \cdot 1^{*}$ & $9 / \% \Delta$ & $\Delta / \wedge \Delta$ & 1 & $\Delta / A \Delta$ & ع ״س آزمون & فيلتر ذهنى \\
\hline$\cdot / \cdot r^{*}$ & $\Lambda / \Delta$ & $\Delta / r Y$ & 1 & $\Delta / \mu r$ & ييخيرى & \\
\hline$\cdot / . \cdot 1^{* * *}$ & YQ/NY & r/qr & 1 & r/qr & 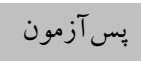 & بى توجهى \\
\hline$\cdot / \cdot \Lambda^{* * *}$ & $r r / \Delta q$ & $r / \cdot \Lambda$ & 1 & $r / \cdot \Lambda$ & بيخيرى & \\
\hline.$/ 19^{* \prime}$ & $\mathrm{V} / \mathrm{Al}$ & $r / T \Delta$ & 1 & $r / T \Delta$ & يس آزمون & نتيجه كيرى شتابزده \\
\hline$\cdot / \cdot Y q^{*}$ & $4 / 1$ & $r / T r$ & 1 & $r / M$ & بيخيرى & \\
\hline
\end{tabular}

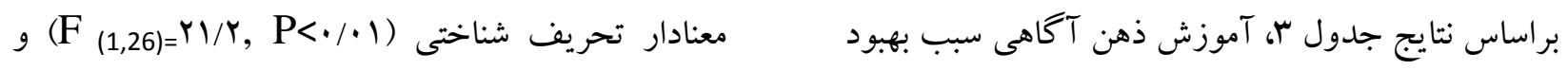

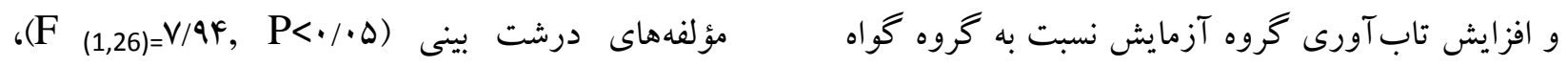

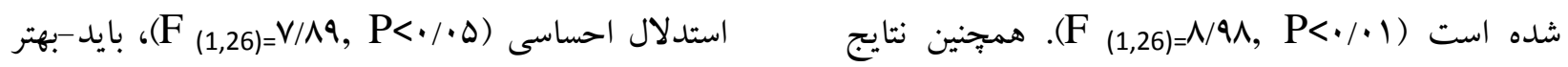

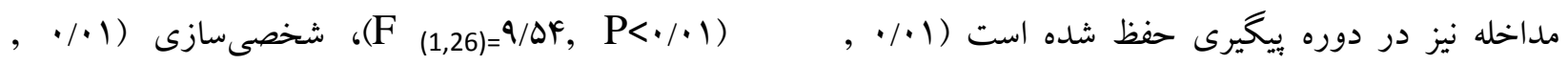

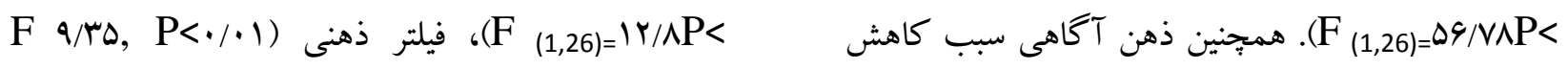


كرايش بيشتر به سمت علائم منجر مىشود؛ بسيارى از

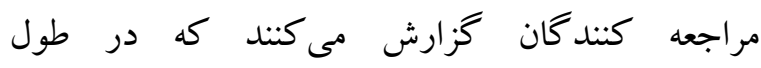
ذهن آكاهى نكران مى شوند ؛ بنابراين تكرار تجربه تمرين ممكن است به افراد ياد بدهد كه آنها مىتوانند نخران

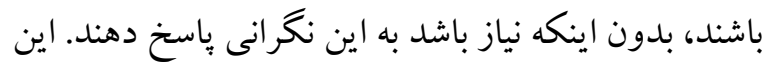

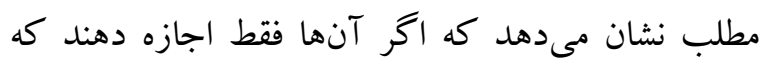
نكران شوند و بر جيز ديخرى تمركز كنند (تنفس شكمى) نخرانى يا تجربهشان از نخرانى تدريجاً تغيير مى كند؛ بنابراين بهواسطه ذهن آكَاهى، بردازش افكار و احساس قابلمشاهده بهعنوان اتفاقات عينى در ذهن روى

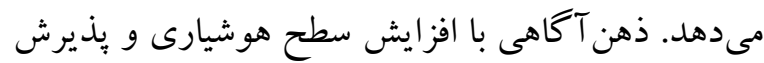
غير قضاوتى افكار و هيجانات مرتبط با آن، نظمبخشى هيجانى را گسترش مىدهد. تجربه اين واكنشهاى هيجانى اطلاعاتى را در مورد ياسخهاى خودكار فيزيولوزيكى در اختيار فرد قرار مىدهد كه اين اطلاعات، خود، مىتواند راهنماى فرد در برخورد با ديخران و ارائه باسخهاى رفتارى مؤثرتر باشد. از سوى ديخر، ارائه اطلاعات در رابطه با اجتناب تجربهاى و آثار منفى متعدد آن در كنار آموزش توجه و به نوعى مواجهه با هيجانات منفى سبب گرديد تا موجب افزايش تاب آورى آزمودنىها افزايش يابد و از ميزان ياسخهاى خود كار را مى كاهد. در تمرينات حضور ذهن از بيمار خواسته نمىشود كه نشانهاى اضطراب را در خود ايجاد كند، بلكه مشاهده بدون داورى حسها كه طبيعتاً بروز مىيابند، مورد ترغيب قرار مى كيرد. اين روش با افزايش آكاهى فرد از تجربيات لحظهى حال و برگرداندن توجه بر سيستم شناختى و و يردازش كارآمدتر اطلاعات، باعث كاهش نخرانى، برانگيختخى فيزيولوزيكك و اضطر ابر و در نتيجه
(1,26)= كيرى شتاب زده (1,26)=V/Al, آزمايش نسبت به گروه گواه شده است كه اين نتايج در دوره بيگيرى نيز بايدار باقى مانده است؛ اما آموزش ذهن

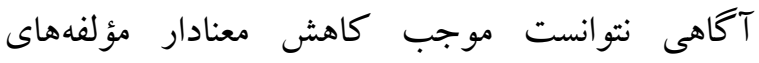

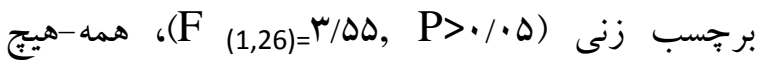

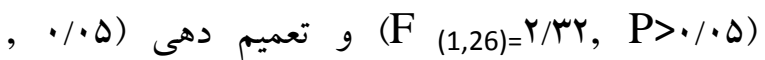
Fر F $_{(1,26)=1 / 9 P>}$

\section{بحث}

نتايج يزوهش حاضر مبنى بر اثربخشى آموزش ذهن آكاهى بر افزايش تابآورى همسو با نتايج مطالعات

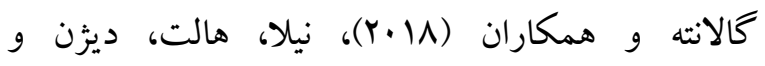
آكويلار-راب (19) و لويرينزى، هيراساد، اسكرودر و

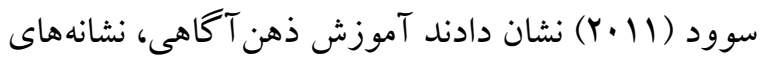
استرس و اضطر اب را كاهش مىدهد و فنون ذهن آكاهى در افزايش آرامبخشى عضلانى و كاهش نخر انى و متعاقباً كاهش اضطراب و در نتيجه افزايش ظرفيت تابآورى

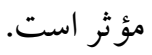
در تبيين اثربخشى آموزش ذهن آكَاهى بر افزايش تاب آورى مىتوان عنوان كرد كه با توجه به سطوح بالاى اضطراب در افراد مبتلا به اختلال روانتنى، سو تعبير از نشانهاى مربوط به موقعيتهاى مختلف منجر به ايجاد يكك جرخه معيوب ترس از ترس مىشود و اين خود موجب ترس از موقعيتهاى مختلف در اين افراد مىشود. اين امر سبب افزايش فراوانى و شدت احساسات بلدنى و روانى ناشى از موقعيتهاى اجتماعى شده و ترس از اين احساسات را شدت مىبخشد. برخلاف باسخهاى خودكار به علائم اضطراب، خود نظارتى علائم به 
در تبيين نتيجه حاضر مىتوان بيان نمود افرادى كه به هنگام تجربه درد، در گير نشخوارهاى فكرى منفى درباره درد مىشوند تا حد زيادى توانايى تمركز بر تجربيات لحظه حال با يك ديدكاه غير قضاوتى را از دست

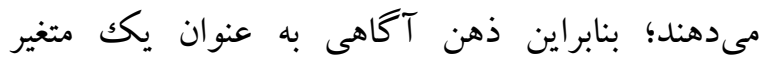
فراشناختى از طريق توقف بردازشهاى مفهومى به تنظيم هيجان كمكك مى كند. اين آكاهى هسته اصلى ذهن آكاهى است كه در آن با به جالش كشيدن تحريفهاى شناختى و يا تلاش براى تغيير آن منجر به بذيرش غير قضاوتى افكار مىشود؛ بنابراين افراد ذذهن آكاه تحريفهاى شناختى كمترى را تجربه مى كنند و اين درمان مىتواند در كاهش تحريفهاى شناختى افراد داراى علائم روانتنى مؤثر باشد (سيرز و كرواسه؛

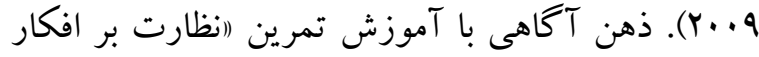
نخران)، موجب آكاهى بيماران نسبت به رابطه بين علائم و افكارشان مى گردد و از طريق ماهيت ذهن آكاهى كه تمركز بر لحظه حال و ديدكاه بدون داورى و قضاوت است، موجب افزايش يذيرش افكار و هيجانات منفى و در نتيجه افزايش انعطاف يذيرى شناختى و از همه مهمتر با ايجاد گسلش شناختى، موجب كاهش تحريفهاى

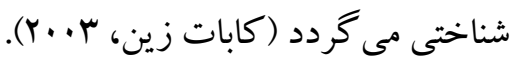
در فر آيند مداخلات ذهن آكاهى، در عوض اينكه فرد را

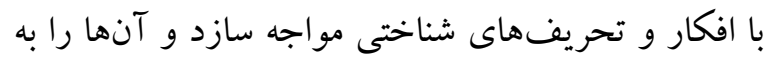
جالش بكشاند، ظرفيت بِّيرش جنين افكارى را بيدا مى كند (شونين، ون گوردون، سلاد و گريفيتس و؛ سا.ب)؛ به عبارتى ديكر، مزيت مداخلات مبتنى بر ذهن آكاهى ناشى از افزايش ظرفيت انعطاف يذيرى روان شناختى است و نه به واسطه ايجاد تغيير در محتواى افكار منفى يا

5. Sears \& Kraus

${ }^{6}$ - Shonin, Van Gordon, Slade \& Griffiths
افزايش ظرفيت مقابلهاى و تابآورى مىشود (كابات زين و هان '، 9. . (Y). ذهن آكاهى به واسطه كاهش تنش ماهيجهاى، منجر به تغييراتى در اضطراب و نكرانى

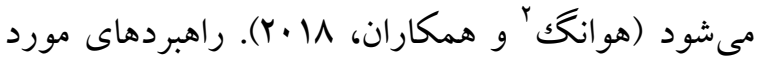
استفاده در اين تمرين، رابطه فرد با تجارب درونىاش را تغيير مىدهد و باعث مىشود مراجع به بِاسخهاى مضطرب كننده توجه كند و به جاى اجتناب، تشويق مىشود تا با آنها مواجه شود و آنها را بيذيرد (نريمانى،

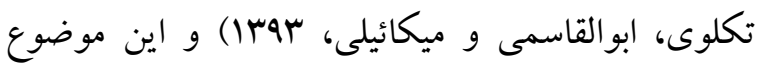
زمينه را براى كاهش نگرانى فراهم مى كند و سبب افزايش تابآورى فرد مى گردد. ذهن آكاهى از طريق ايجاد آكاهى نسبت به افكار، رفتار، هيجانات و و احساسات، سبب ايجاد شكل خاصى از توجه مىشود كه در آن دو عنصر اساسى حضور در زمان اكنون و قضاوت نكردن در مورد رخدادها و كنشها و واكنشها نقش اصلى را به عهده دارند (آقا يوسفى، اوركى، زارع و ايمانى، بوسا). همجنين با ارائه آموزشهايى در راستاى شناسايى هيجانهاى منفى و مديريت آنها، زمينه را براى افزايش بازخوردهاى مثبت و در نتيجه افزايش تابآورى

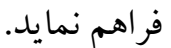
نتايج بثزوهش حاضر مبنى بر اثربخشى آموزش ذهن آكاهى بر كاهش تحريفهاى شناختى همسو با نتايج

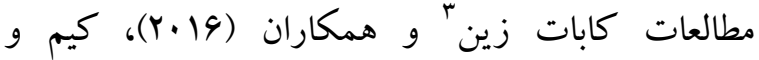
همكاران (Y.19) و اوستافين و و همكاران (Y.4. (Y) بود كه دريافتند يافتهاى آنها نيز نشان داد كه استفاده از درمان

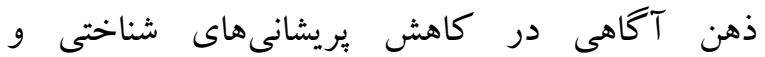
تحريفهاى شناختى اثر گذار بوده است.

\footnotetext{
1- Kabat-Zinn \& Hanh

2- Hwang

${ }^{3}$ - Kabat-Zinn

${ }^{4}$ - Ostafin
} 
تغييرات فيزيولوزيكك در افراد شده كه اين موضوع خود

با كاهش تحريفهاى شناختى مرتبط است. همجينين به كارگيرى تكنيكك هاى مراقبه و اسكن بدن در جهت افزايش فهم و آكاهى از افكار و احساسات و حسهاى بدنى خودكار و غير ارادى، برنامه ريزى شده است؛ به طورى كه بتوان با به كارگيرى تكنيك هاى آن، باسخهاى وابسته به اين افكار، احساسات و حسهاى بدنى را از حالت خود كار خارج كرده و در بروز و تجربه آنها تغيير ايجاد كرد. ايجاد هنين آكاهى در افراد از تحريفهاى شناختى ناشى از علائم جسمانى مى كاهد

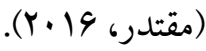

\section{نتيجه كيرى}

مطالعه حاضر حاكى از اثربخش بودن آموزش ذهن آكاهى در كاهش تحريفات شناختى و افزايش تاب آورى بيماران مبتلا به اختلالات روانتنى بود؛ لذا در مراحل مختلف درمان يا بِ از آن مىتوان با ارائه اين دسته از

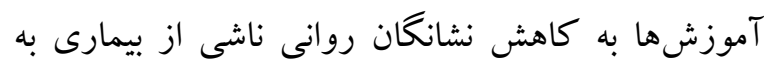
بيماران كمك كرد. آموزش فنون ذهن آكاهى به عنوان مهارتهاى ساز كارى مىتواند بسيارى از مشكلات بيماران را كاهش دهد و موجب افزايش توان آنها را براى ساز كارى با شرايط كنونى گردد. بيخيرى و انجام تمرينات ذهن آكاهى يس از مدتى مىتواند با تغييرات قابل ملاحظهاى در زندگى بيماران و كاركردهاى روان شناختى آنها همراه شود و از طريق توسعه راهبردهاى كنار آمدن و سازو كارهاى دفاعى بهتر در افراد موجب بهبود بهزيستى روانى آنها گردد. افراد مى آموزند در مواجهه با وقايع ناخوشايند، ارزيابى مجدد مثبت را به كار كيرند، به وسيله آموزش مهارتهاى مقابلهاى، در مواجهه با رويدادهاى استرسزا با خوشبينى و اعتماد به نفس
تحريفهاى شناختى. بر همين اساس، در مداخلات ذهن آكاهى باور بر اين است كه صرفاً كافى است كه فرد ظرفيت يذيرش هنين افكارى رادر خود يرورش دهد و لزومى ندارد كه مراجع با افكار ناكارآمد خود مقابله كرده و يا آنها را به جالش بكشد (فلكسمن و باند'،

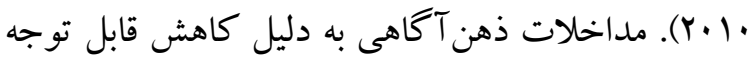
واكنشيذيرى شناختى و هيجانى، از توانايى تغيير عو اطف و هيجانها برخوردارند. به بيانى ديخر، مزيت هر نوع آكاهى هدفدار اين است كه ظرفيت جذب محدودى براى افكار باقى مى گذارد، در نتيجه، فرصتى براى نشخوار فكرى باقى نمىماند (برايتون، شاهر،

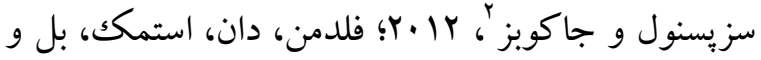

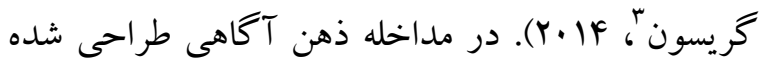
براى بيماران داراى علائم جسمانى، توجه آكًاهانه به زمان حال، معطوف به هدف و بدون داورى و خالى از قضاوت

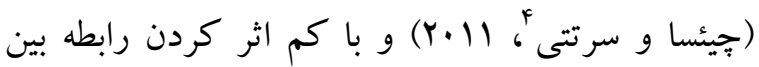
واكنش افكار و نتايج ضعيف (كويكنه و همكاران،

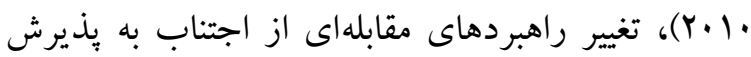
احساسات و افكار، باعث تغييرات شناختى و در نتيجه كاهش تحريف هاى شناختى در بيماران مبتلا به اختلال روانتنى مى گردد. علاوه بر استفاده از تكنيككهاى

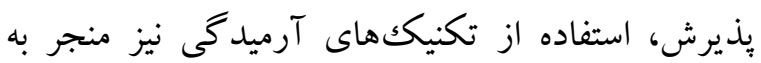
كاهش تحريفهاى شناختى مى گردد جرا كه افزايش مهارتهاى شناختى و رفتارى مىتواند از تحريفهاى شناختى به وجود آمده از علائم و نشانه هاى فيزيولوزيك و در نتيجه ملديريت استرس به شيوه شناختى - رفتارى بكاهد؛ بنابراين انجام تمرين هاى آرميدگى منجر به

\footnotetext{
1- Flaxman \& Bond

2- Britton, Shahar, Szepsenwol \& Jacobs

3 - Feldman, Dunn, Stemke, Bell \& Greeson

${ }^{4}$ - Chiesa \& Serretti

5 - Kuyken
} 
منسجم و بربار و وسيعتر جهت بهبود وضعيت اين افراد داشت و از سوى ديخر يثزوهشخرانى كه در حيطه اختلالات روانتنى به مطالعه مى يردازند را كمك نموده

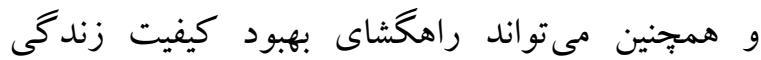
بيماران با ارائه ديد گاههاى كلى باشد.

\section{سياسگزارى}

بدين وسيله از تمامى شركت كنند گان و همجينين روان يزشكان و يزشكانى كه در بزّوهش حاضر همكارى داشتهاند، تقدير و تشكر به عمل مى آيد.

\section{References}

AbbottRA, Whear R, Rodgers LR, Bethel A, Coon JT, Kuyken W, Dickens C. (2014). Effectiveness of mindfulness-based stress reduction and mindfulness based cognitive therapy in vascular disease: A systematic review and meta-analysis of randomised controlled trials. Joumal of psychosomatic research, 76(5), 341-351.

Abdollahzade H, Salar M. (2010). Creating and standardizing a cognitive distortion questionnaire. Tehran. (In Persian)

Agha Yoosefi A, Oraki M, Zare M, Imani S. (2013). Effectiveness of Mindfulness in Decreasing Stress, Anxiety and Depression among the Substance Abusers. Journal of clinical Psychology (Andishe va Raftar), 8(27), 17-26. (In Persian)

American Psychiatric Association. (2013). Diagnostic and statistical manual of mental disorders (DSM-5®). American Psychiatric Pub.

Barsky AJ. (2016). Assessing the new DSM-5 diagnosis of somatic symptom disorder.Psychosomatic medicine, 78(1), 2-4.

Belir S, Erfani N, Safaeerad I. (2016). The relationship between cognitive distortions and quality of life among postmenopausal, infertile, under hysterectomy, uterine leiomyoma and normal females. Health Research, 1(4), 207-14.
برخورد كرده، رويدادها را قابل كنترل تلقى مى كنند و به طور كلى سيستم يردازش اطلاعات خود را به شيوهى مؤثرترى به كار مىاندازند. از سوى ديخر، آموزش ذهن آكاهى با تقويت فرايندهاى مقابلهى شناختى همانند ارزيابى مجلد مثبت و تقويت مهارتهاى تنظيم هيجان مثل تابآورى و تحمل يريشانى، آموزش حل مسئله و آموزش فنون ناديده گرفتن، مىتواند از فرد در مقابل بد عملكردى خُلقى ناشى از استرس و نشخوار در هنگام شروع حملات استرس محافظت كند. با توجه به اين كه گروه كنترل در يكك برنامه گروهى براى كنترل تأثير بويايى گروه شركت نكرد (جهت كسب اطمينان بيشتر نسبت به اثربخشى مداخله)، همجِين با توجه به اينكه افراد نمونه از يكك شهر انتخاب شدهاند و نبودن تحقيقات مشابه در اين زمينه كه مقايسه يافتها را نسبتاً محدود مى كند، به همين جهت در تعميم يافتها بايستى جانب احتياط رعايت شود. با توجه به اثربخشى آموزش ذهن آكاهى، لزوم تمركز بر اين برنامه آموزشى

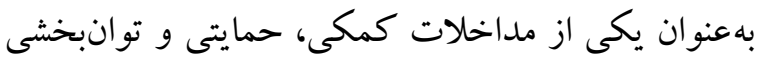
در كنار ساير حمايتهاى روانى-اجتماعى در كاهش تحريفات شناختى و ارتقاى توانايى و ظرفيت مقابلهاى بيماران مبتلا به اختلالات روانتنى بيشنهاد مىشود. در نهايت، با توجه به كستردگى اثرات اين اختلال، از طريق برنامهريزى، ارائه كاركاههاى آموزشى براى اين افراد و خانودههايشان به توانمندسازى آنان برداخت و از اين طريق سبب بيشخيرى و يا كاهش مسائل و ييامدهاى برآمده از اين اختلال گرديد. با بررسى تحريفهاى

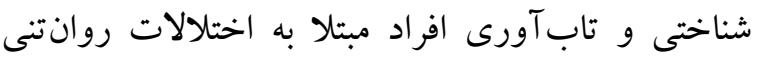
مىتوان كمكك شايانى به سياست گذاران و برنامه ريزان عرصهاى حمايتى و اجتماعى جهت برنامهريزىهاى 
Bohlmeijer E, Prenger R, Taal E, Cuijpers P. (2010). The effects of mindfulness-based stress reduction therapy on mental health of adults with a chronic medical disease: a metaanalysis. Joumal of psychosomatic research, 68(6), 539-544.

Britton WB, Shahar B, Szepsenwol O, Jacobs WJ. (2012). Mindfulness-based cognitive therapy improves emotional reactivity to social stress: results from a randomized controlled trial. Behavior therapy, 43(2), 365-380.

Butzer B, Kuiper NA. (2006). Relationships between the frequency of social comparisons and selfconcept clarity, intolerance of uncertainty, anxiety, and depression. Personality and individual differences, 41(1), 167-176.

Chiesa A, Serretti A. (2011). Mindfulness based cognitive therapy for psychiatric disorders: a systematic review and metaanalysis. Psychiatry research, 187(3), 441-453.

Connor KM, Davidson JR. (2003). Development of a new resilience scale: The Connor-Davidson resilience scale (CD-RISC). Depression and anxiety, 18(2), 76-82.

Farmani-shahreza S, Bahmani B, Ghaedniay-jahromi A. (2017). The Effect of Cognitive-Existential Therapy on Cognitive Distortions in Women with HIV: A Single-Subject Study. Iranian Journal of Psychiatry Nursing, 5 (3), 48-57. (In Persian)

Feldman G, Dunn E, Stemke C, Bell K, Greeson J. (2014). Mindfulness and rumination as predictors of persistence with a distress tolerance task. Personality and individual differences, 56, 154-158.

Flaxman PE, Bond FW. (2010). A randomised worksite comparison of acceptance and commitment therapy and stress inoculation training. Behaviour research and therapy, 48(8), 816-820.

Galante J, Dufour G, Vainre M, Wagner AP, Stochl J, Benton A, Jones PB. (2018). A mindfulnessbased intervention to increase resilience to stress in university students (the Mindful Student Study): a pragmatic randomised controlled trial. The Lancet Public Health, 3(2), e72-e81.

Goetzmann L, Siegel A, Ruettner B. (2019). The connectivity/conversion paradigm-A new approach to the classification of psychosomatic disorders. New Ideas in Psychology, 52, 26-33.

Haftgoli N, Favrat B, Verdon F, Vaucher P, BischoffT, Burnand B, Herzig L. (2010). Patients presenting with somatic complaints in general practice: depression, anxiety and somatoform disorders are frequent and associated with psychosocial stressors. BMC family practice, 11(1), 67.

Hagh Ranjbar F, Kakavand A, Borjali A, Bermas H. (2011). Resilience and quality of mothers with children with mental disabilities. Quarterly Journal of Health and Psychology, 1(1), 177187. (In Persian)

Haller H, Cramer H, Lauche R, Dobos G. (2015). Somatoform disorders and medically unexplained symptoms in primary care: a systematic review and meta-analysis of prevalence. Deutsches Ärzteblatt International, 112(16), 279.

Hofmann SG, Sawyer AT, Witt AA, Oh D. (2010). The effect of mindfulness-based therapy on anxiety and depression: A meta-analytic review. Joumal of consulting and clinical psychology, 78(2), 169.

Hwang WJ, Lee TY, Lim KO, Bae D, Kwak S, Park HY, Kwon JS. (2018). The effects of four days of intensive mindfulness meditation training (Templestay program) on resilience to stress: a randomized controlled trial. Psychology, health \& medicine, 23(5), 497-504.

Janowski K, Łucjan P. (2012). P-133-Worry and mindfulness: the role in anxiety and depressive symptoms. European Psychiatry, 27, 1.

Kabat-Zinn J, de Tomijos F, Skillings AH, Blacker M, Mumford GT, Alvares DL, Rosal MC. (2016). Delivery and Effectiveness of a Dual Language (English/Spanish) MindfulnessBased Stress Reduction (MBSR): Program in the Inner City-A Seven-Year Experience: 
1992-1999. Mindfulness \& Compassion, 1(1), 2-13.

Kabat-Zinn J, Hanh TN. (2009). Full catastrophe living: Using the wisdom of your body and mind to face stress, pain, and illness. Delta.

Kabat-Zinn J. (2003). Mindfulness-based interventions in context: past, present, and future.Clinical psychology: Science and practice, 10(2), 144 156.

Kim MK, Lee KS, Kim B, Choi TK, Lee SH. (2016). Impact of mindfulness-based cognitive therapy on intolerance of uncertainty in patients with panic disorder. Psychiatry investigation, 13(2), 196.

Koh KB. (2018). Cognitive behavioral therapy for patients with chronic headache. In Stress and Somatic Symptoms (pp. 207-216). Springer, Cham.

Kolahkaj B, Zargar F. (2015). Effect of mindfulnessbased stress reduction on anxiety, depression and stress in women with multiple sclerosis. Nursing and midwifery studies, 4(4).

Kuyken W, Watkins E, Holden E, White K, Taylor RS, Byford S, Dalgleish T. (2010). How does mindfulness-based cognitive therapy work? Behaviour research and therapy, 48(11), 1105-1112.

Loprinzi CE, Prasad K, Schroeder DR, Sood A. (2011). Stress Management and Resilience Training (SMART) program to decrease stress and enhance resilience among breast cancer survivors: a pilot randomized clinical trial. Clinical breast cancer, 11(6), 364-368.

Lovas DA, Barsky AJ. (2010). Mindfulness-based cognitive therapy for hypochondriasis, or severe health anxiety: A pilot study. Journal of anxiety disorders, 24(8), 931-935.

Mikocka-Walus A, Bampton P, Hetzel D, Hughes P, Esterman A, \& Andrews JM. (2017). Cognitive-behavioural therapy for inflammatory bowel disease: 24-month data from a randomised controlled trial. International journal of behavioral medicine, 24(1), 127-135.

Moghtader L. (2016). The effectiveness of mindfulnessbased cognitive therapy in reducing rumination, dysfunctional attitude and negative automatic thoughts in patients with generalized anxiety disorders. The Joumal of Urmia University of Medical Sciences, 27(9), 825835. (In Persian)

Narimani M, Taklavi S, Abolghasemi A, Mikaili N. (2015). The Effectiveness of Applied Relaxation Training Based on Mindfulness and Cognitive-Behavioral Therapy on Anxiety Sensitivity of Women with Generalized Anxiety Disorder. Joumal of clinical psychology, 6, 3(23), 13-22. (In Persian)

Nila K, Holt DV, Ditzen B, Aguilar-Raab C. (2016). Mindfulness-based stress reduction (MBSR) enhances distress tolerance and resilience through changes in mindfulness. Mental Health \& Prevention, 4(1), 36-41.

Onur OS, Ertem DH, Karsidag C, Uluduz D, Ozge A, Siva A, Guru M. (2019). An open/pilot trial of cognitive behavioral therapy in Turkish patients with refractory chronic migraine. Cognitive neurodynamics, 13(2), 183-189.

Ostafin BD, Chawla N, Bowen S, Dillworth TM, Witkiewitz K, Marlatt GA. (2006). Intensive mindfulness training and the reduction of psychological distress: A preliminary study. Cognitive and Behavioral Practice, 13(3), 191-197.

Rosenberg J, Lechea N, Pentang GN, Shah NJ. (2019). What magnetic resonance imaging reveals $-\mathrm{A}$ systematic review of the relationship between type II diabetes and associated brain distortions of structure and cognitive functioning. Frontiers in neuroendocrinology, 52, 79-112.

Rosenzweig S, Greeson JM, Reibel DK, Green JS, Jasser SA, Beasley D. (2010). Mindfulnessbased stress reduction for chronic pain conditions: variation in treatment outcomes and role of home meditation practice. Journal of psychosomatic research, 68(1), 29-36.

Sayyar S, Ghanbari MR, Omid A, Scheidt CE, Giveki R, Mohammadian R. (2019). Effectiveness of Acceptance and Commitment Therapy on 
اب بررسى اثربخشى ذهن آكاهى بر تابَآورى و تحريف شناختى بيماران با علائم جسمانى

Psychosomatic Symptoms and Mindfulness

in Patients With Psychosomatic

Disorders. Practice in Clinical

Psychology, 7(2), 79-86.(In Persian)

Sears S, Kraus S. (2009). I think therefore I om: Cognitive distortions and coping style as mediators for the effects of mindfulness meditation on anxiety, positive and negative affect, and hope. Joumal of clinical psychology, 65(6), 561-573.

Shonin E, Van Gordon W, Slade K, Griffiths MD. (2013). Mindfulness and other Buddhistderived interventions in correctional settings: A systematic review. Aggression and Violent Behavior, 18(3), 365-372.

Simi L, Fava GA. (2013). Diagnostic criteria for psychosomatic research and somatic symptom disorders. Intemational Review of Psychiatry, 25(1), 19-30.

Vollestad J, Sivertsen B, Nielsen GH. (2011). Mindfulness-based stress reduction for patients with anxiety disorders: Evaluation in a randomized controlled trial. Behaviour research and therapy, 49(4), 281-288.

Yang Y, Liu YH, Zhang HF, Liu JY. (2015). Effectiveness of mindfulness-based stress reduction and mindfulness-based cognitive therapies on people living with HIV: A systematic review and metaanalysis. Intemational Joumal of Nursing Sciences, 2(3), 283-294.

Yücel B, Kora K, Özyalçín S, Alçalar N, Özdemir Ö, Yücel A. (2002). Depression, automatic thoughts, alexithymia, and assertiveness in patients with tension-type headache. Headache: The Joumal of Head and Face Pain, 42(3), 194-199.

Zeidan F, Johnson SK, Gordon NS, Goolkasian P. (2010). Effects of brief and sham mindfulness meditation on mood and cardiovascular variables. The Journal of Altemative and Complementary Medicine, 16(8), 867-873. 